\title{
Acute Stress Response in Women with Recurrent Miscarriage and Infertility
}

\author{
Bhandari Sunita ${ }^{1}$ \\ ${ }^{1}$ Department of Obstetrics and Gynaecology, KIST Medical College, Lalitpur, Nepal
}

\section{ABSTRACT}

Introduction: Stress has been linked to reproductive failure which includes miscarriage and Infertility. Several studies showed high levels of psychological stress and stress biomarkers in women with reproductive failure. However, very few studies are done to measure the stress response. So the current study sought to assess whether women with reproductive failure have exaggerated acute stress response.

Materials and Methods: This was a cross-sectional comparative study. Blood samples were collected immediately after venipuncture, and again 20 min later from 15 fertile controls, 20 recurrent miscarriage patients, and 40 infertile patients to measure natural killer cells and cortisol levels.

Results: The percentage of peripheral blood NK cells (total CD3-CD56+) and serum total cortisol level did not change significantly across the two samples of immediately after venipuncture, and again 20 min later in the fertile controls $(\mathrm{p}=0.358$, and $\mathrm{p}=0.890$ respectively). However, there was a significant decline in the second sample in women with Infertility $(p<0.05$ for serum cortisol and $\mathrm{p}<0.05$ for NK cell) and with recurrent miscarriage $(\mathrm{p}<0.05$ for serum cortisol). There was a decline of NK cell in the $2^{\text {nd }}$ sample in women with recurrent miscarriage though not to significant level $(\mathrm{P}>0.05)$.

Conclusions: Women with recurrent miscarriage and Infertility may be more vulnerable to acute stressor.

Keywords: Cortisol; Infertility; Miscarriage; NK-cell; Stress
Copyright: This is an open-access article distributed under the terms of the Creative Commons Attribution 4.0 International License, which permits unrestricted use, distribution, and reproduction in any medium, provided the original author and source are credited.

\section{Correspondence:}

Dr. Sunita Bhandari, MD

Department of Obstetrics and Gynaecology KIST Medical College, Lalitpur, Nepal ORCID ID: 0000-0002-7371-5969

Email: nusita5@hotmail.com

Submitted: $7^{\text {th }}$ January 2018

Accepted: $19^{\text {th }}$ April 2018

Published: $1^{\text {st }}$ June 2018

Conflict of Interest: None Sources of Support: None

Citation: Bhandari S. Acute Stress response in women with Recurrent Miscarriage and Infertility. Nep Med J 2018;1:17-20. DOI: 10.3126/nmj.v1i1.20393

\section{INTRODUCTION}

When a situation is perceived as stressful, the HypothalamicPituitary- Adrenal axis becomes activated, causing a cascade of hormones to be produced that may negatively impact reproduction. The paraventricular nucleus of the hypothalamus releases corticotropin-releasing factor, which stimulates the pituitary gland to releases adrenocorticotropic hormone that results in the secretion of glucocorticoids from the adrenal cortex. Increase in serum concentration of glucocorticoids in humans and rhesus monkeys evidently suppresses the hypothalamic-pituitaryovarian axis. ${ }^{1}$

Moreover, natural killer (NK) cells have been described to be up-regulated during stress. ${ }^{2}$ Even mild psychological stress and moderate physical activity rapidly recruit large numbers of NK cells into the circulation, an effect which subsides shortly after the stress ceases. ${ }^{3,4}$ The increased NK cell number and activity previously observed in recurrent miscarriage patients may results from mobilization of NK cells in response to stress of venipuncture which is more pronounced in patients with primary recurrent miscarriages than secondary recurrent miscarriages. ${ }^{5}$ Psychotherapy has been reported to decrease in both psychological distress and NK-cell activity in infertile women, resulting in an increased pregnancy rate. ${ }^{6}$ Stress elevation of NK activity and NK cell mobilization support a known pathophysiological link between NK cells and reproductive failure.

Considering the fact that the mobilization of NK cells represents one of the most reliable stress responses, it is surprising that 
only a few attempts have been made to further characterize this phenomenon in women with reproductive failure. The majority of research has been done showing the effect of stress in causing miscarriage and Infertility but very few studies are there to characterize the response to stress, whether women with reproductive failure have same response to stress as normal fertile women. The aim of this study was to assess the acute stress response in women with reproductive failure. We hypothesized that venipuncture could be stressful, stress marker (NK cell, Cortisol) would be lower in the second sample drawn 20 minutes later, after patients adjust to the situation.

\section{MATERIALS AND METHODS}

A cross-sectional comparative study was conducted after approval from Recurrent Miscarriage Clinic and Reproductive Medicine Centre in First Affiliated Hospital of Sun Yat-Sen University, Guangzhou, China from October 2009 to May 2010. Permission was obtained from the institutional review committee. Seventy five women of age between 25-40 years were consented to the study. All the study population was grouped into i) Infertility group, ii) recurrent miscarriage (RM) group and iii) control group. Infertility group: Infertile women with tubal and/or male factor infertility undergoing IVF/ICSI treatment cycle on day 3-5 of menstrual cycle, i.e. on the day of ovarian stimulation, after down-regulation with $\mathrm{GnRH}$ agonist (Triptorelin $1.0 \mathrm{mg}$ s.c) on the mid-luteal phase (D20) of previous month in a long protocol with no previous live birth.

Recurrent Miscarriage group: Recurrent miscarriage women with last abortion at least 6 months prior to the study, with no previous live birth, with history of at least 3 or more consecutive miscarriages with negative biomedical screening test which included: a) karyotype of both parents, b) ovarian function test (LH, FSH, E2, P, PRL,T), c) thyroid function test, d) endometrial biopsy, e) mid-luteal progesterone, f) blood group, g) antinuclear antibody, h) anti-mitochondrial antibody, i) anti-smooth muscle antibody, j) anti-thyroid antibodies, k) anti-phospholipid antibodies (IgM and IgG anticardiolipin antibodies, beta-2 glycoprotein), 1) protein $\mathrm{C}$ activity, $\mathrm{m}$ ) protein $\mathrm{S}$ activity, $\mathrm{n}$ ) antithrombin III activity, o) activated protein $\mathrm{C}$ resistance, $\mathrm{p}$ ) factor VIII, q) fibrin degradation product, r) plasminogen activator inhibitor, s) pelvic ultrasonogram, t) full blood count, $\mathrm{u}$ ) infectionantibody screen (TORCH), and $\mathrm{u}$ ) sperm investigation of partner (morphology and DNA fragmentation) thereby excluding genetic, endocrinologic, thrombophilic, uterine, autoimmune cause, infectious cause, or male factors.

Fertile control group: Fertile women as control with no history of consecutive miscarriage and have at least one live birth, without using any hormonal methods of contraception.

\section{Experimental procedure}

An intravenous cannula was inserted, and blood was collected immediately after cannulation, and again 20 minutes later between 8:00-10:00am. Venous blood for serum total cortisol was collected in serum separator tube (BD Vacutainer ${ }^{\circledR}$ SST $\left.{ }^{\mathrm{TM}} \mathrm{II}\right)$, and measured by ARCHITECT Cortisol Chemiluminescent microparticle Immunoassay (CMIA) on the Architect i2000 System (Abbott, IL, USA).
Heparinized peripheral blood was obtained and analysed within $8 \mathrm{~h}$ of collection. Aliquots of $1 \mathrm{ml}$ of whole blood was added $5 \mathrm{ml}$ of erythrocytes lysing solution (OptiLyse ${ }^{\circledR} \mathrm{C}$, Immunotech, Beckman Coulter) and washed once with $0.9 \%$ normal saline solution. The cell preparation was incubated for $30 \mathrm{~min}$ at room temperature in the dark with the following mouse antihuman antibodies: PE Mouse Anti-Human CD56, FITC Mouse Anti-Human CD16 (BD) and CD3-ECD Conjugated Antibody (Beckman Coulter). Fluorescence-activated cell sorter (FACScan, Beckman Coulter, USA) analysis was used to assess the number of NK cells in the blood. Natural-killer cells were identified as CD3 ${ }^{-} \mathrm{CD} 56^{+} \mathrm{CD} 16^{+}, \mathrm{CD} 3{ }^{-} \mathrm{CD} 56^{+} \mathrm{CD} 16^{-}, \mathrm{CD} 3{ }^{-} \mathrm{CD} 56^{+}$.

\section{Statistical Analysis}

Analysis of variance (ANOVA) was performed using SPSS Windows version 13 (SPSS Inc., USA). The results were reported to be statistically significant if the $\mathrm{P}$ value was $<0.05$.

\section{RESULTS}

A total of 75 females were included in the study, out of which 20 females were in recurrent miscarriage group, 40 were in infertile group and 15 were of control groups. Mean age of the study population was 32.54 years. Table 1 summarizes mean age, parity, number of miscarriages and duration of Infertility in the three groups.

Table 1: Patients' characteristics among study population

\begin{tabular}{lccc}
\hline & $\begin{array}{c}\text { RM } \\
(\mathbf{n}=\mathbf{2 0})\end{array}$ & $\begin{array}{c}\text { Infertile } \\
(\mathbf{n}=\mathbf{4 0})\end{array}$ & $\begin{array}{c}\text { Control } \\
(\mathbf{n}=15)\end{array}$ \\
\hline Age (years) & $32.65 \pm 3.58$ & $32.07 \pm 3.8$ & $32.91 \pm 3.96$ \\
\hline Parity & $0 \pm 0$ & $0 \pm 0$ & $1.13 \pm 0.3$ \\
\hline $\begin{array}{l}\text { No. of } \\
\text { miscarriages }\end{array}$ & $4.05 \pm 1.5$ & $0 \pm 0$ & $0 \pm 0$ \\
$\begin{array}{l}\text { Years of } \\
\text { Infertility }\end{array}$ & $0 \pm 0$ & $4.9 \pm 2.7$ & $0 \pm 0$ \\
\hline
\end{tabular}

The mean serum total cortisol level at first blood withdrawal was $11.42 \mu \mathrm{g} / \mathrm{dl}$. (Table 2) The mean $\pm \mathrm{SD}$ of serum total cortisol level and number of peripheral NK cell $\left(\mathrm{CD} 3{ }^{-} \mathrm{CD} 56^{+}\right)$between the groups, in the first (immediately after cannulation) and second blood withdrawal (20 min later) are shown in Table 2 and Table 3 respectively. $\mathrm{P}$ value was not significant for serum total cortisol level among RM or Infertile subgroup vs. control group $(\mathrm{P}>0.05)$. $\mathrm{P}$ value was significant for NK-cells among $\mathrm{RM}$ or infertile subgroup Vs. control group $(\mathrm{P}<0.05)$.

The serum total cortisol level and the percentage of peripheral blood NK cells did not change significantly across the two samples in the fertile control group $(\mathrm{p}=0.358$, and $\mathrm{p}=0.890$ respectively). However, there was a significant decline in the second sample in infertile group: $\mathrm{p}=0.007$ for serum cortisol and $\mathrm{p}=0.000$ for NK cell. There was a significant decline of serum cortisol in RM group in the second sample $(\mathrm{p}=0.005)$ but the decline of NK cell was not significant ( $\mathrm{p}=0.220$ ); Figure 1 and Figure 2 . 
Table 2: Levels of serum cortisol in the first and second blood withdrawal.

\begin{tabular}{ccccc}
\hline Serum Coritsol & $\begin{array}{c}\text { RM } \\
(\mathbf{n = 2 0 )}\end{array}$ & $\begin{array}{c}\text { Infertile } \\
(\mathbf{n = 4 0 )}\end{array}$ & $\begin{array}{c}\text { Control } \\
(\mathbf{n = 1 5})\end{array}$ & F value \\
\hline First blood withdrawal & $10.50 \pm 2.70$ & $12.53 \pm 4.0$ & $11.25 \pm 4.37$ & 1.463 \\
Second blood withdrawal & $9.29 \pm 3.55$ & $11.32 \pm 3.44$ & $10.64 \pm 3.46$ & 0.238 \\
\hline
\end{tabular}

Table 3: Levels of peripheral NK cells in the first and second blood withdrawal.

\begin{tabular}{cccccc}
\hline NK cells & RM & $\begin{array}{c}\text { Infertile } \\
(\mathbf{n = 4 0 )}\end{array}$ & $\begin{array}{c}\text { Control } \\
(\mathbf{n = 1 5})\end{array}$ & F value \\
\hline First blood withdrawal & $22.03 \pm 11.62^{*}$ & $47.29 \pm 8.42^{*}$ & $10.41 \pm 5.80$ & 10.858 \\
\hline Second blood withdrawal & $20.05 \pm 10.54^{*}$ & $42.42 \pm 8.89^{*}$ & $10.31 \pm 5.17$ & 87.187
\end{tabular}

Note: Values are Mean $\pm \mathbf{S D} ;{ }^{*} \mathbf{p}<\mathbf{0 . 0 5}$ is significant, $\mathbf{R M}$ or Infertile subgroup vs. control group.

\section{DISCUSSION}

This study showed that percentage of peripheral blood NK cell and serum cortisol level did not change significantly across the two blood withdrawals i.e immediately after cannulation, and 20 minutes later in the fertile control group. However, the NK cell level and the cortisol level decline significantly in second sample when blood is again drawn from the same cannula 20 min later in women with reproductive failure. The declines were statistically significant in infertile women undergoing GnRH down-regulated IVF/ICSI cycle, whose NK cell level was the highest in the first blood withdrawal. But, NK levels were still significantly higher in infertile and RM group as compared to fertile control group in the second blood withdrawal. It could be that these women are exposed to the long-term stressful event as a result of recurrent miscarriage or infertility and its treatment, and such a chronic stress, may underpin the basis for these patients' persistently high NK cells, as seen in our study. This is in contrast to finding from Shakhar et $\mathrm{al}^{5}$, who found that the level of NK cell in women with $\mathrm{RM}$ in the second blood withdrawal declined to values similar to those seen in the control group. The discrepancy may be due to the small sample size (14 primary recurrent miscarriages, 1 missing data). In addition, no any stress markers were used in the study to measure stress level across the two blood withdrawals so as to confirm the stress-induced NK mobilization, we used serum cortisol to measure stress level across two blood withdrawal.

Overall our results suggest that women with reproductive failure are hyper-responsive to acute stress. They perceive venepuncture as stressful, probably because they think blood test as critical for their diagnosis and treatment outcome. The physiological acute stress response in human is primarily characterized by an

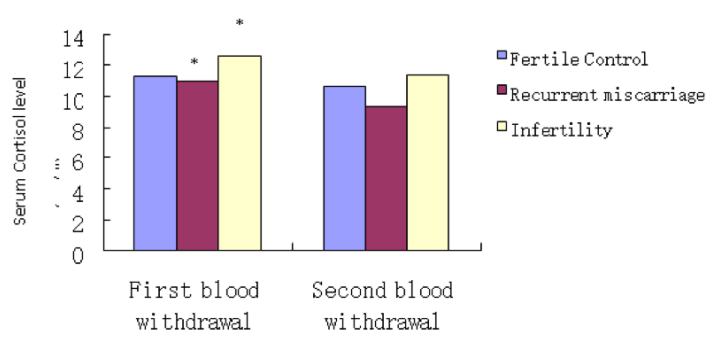

Figure 1: Serum total cortisol $(\operatorname{mean} \pm \mathrm{SD})$ in the first and second blood withdrawal in recurrent miscarriage, infertile and fertile control group. $(*)$ denotes significant differences $(p=<0.05)$ : First blood withdrawal vs. Second blood withdrawal. activation of both the sympathetic nervous system (SNS) and the hypothalamic-pituitary-adrenocortical (HPA) axis resulting in increased plasma concentrations of catecholamines (epinephrine, norepinephrine) and glucocorticoids (cortisol). NK cells have been found to express highest $\beta$-adrenergic receptors ${ }^{7}$ and they increase rapidly in response to acute psychologic stressors. ${ }^{8-10}$ This response reflects a release of NK cells from various reservoirs such as the margins of the blood vessels into the blood. In our study although, we did not observe high level of cortisol in women with reproductive failure in the first blood withdrawal, but the significant subsequent decline of cortisol together with NK cells in the second blood withdrawal seen only in these population and not in the fertile control group, gives an indirect evidence of enhanced stress response to venepuncture in women with RM and infertile women undergoing IVF treatment.

Our finding is also in agreement with that of a previous study of Facchinetti et al. ${ }^{11}$ who concluded that infertile women undergoing IVF-ET treatment have an increased reaction to stress. Infertile women were tested on the day of oocyte pick -up and were submitted to Stroop Color and Word test, a task measuring the ability to cope with a cognitive stressor, involving attentional and sympathoadrenal systems. Systolic (SBP) and diastolic blood pressure, as well as heart rate (HR) were measured at baseline, during the test, and 10 minutes after the end of testing to measure stress response. Although the sample size was small (16 pregnant, 33 not pregnant), every subject reported an increase of cardiovascular parameters and the women becoming pregnant showed a lower response of both SBP and HR than women who failed.

The mobilization of NK cell among women with reproductive failure, especially in the infertile women is probably more than a specific response to the blood test and may be representative

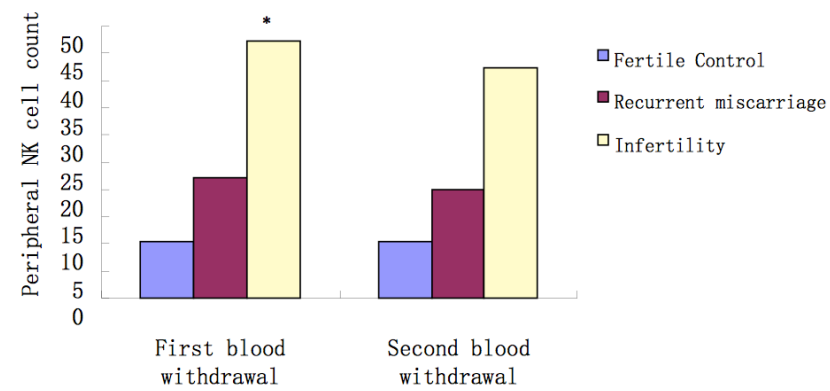

Figure 2: Percentage of NK cells (mean \pm SD) in the first and second blood withdrawal in recurrent miscarriage, infertile and fertile control group. $(*)$ denotes significant differences $(p=<0.05)$ : First blood withdrawal vs. Second blood withdrawal. 
of the response of these women to other stressors they encounter in everyday life. It could be that a greater sympathetic response to stressor leads to an enhanced increase in NK cell number and activity, accounting for negative impact on reproduction. Increased numbers of NK cells were found in the peripheral blood of women with reproductive failure ${ }^{12-16}$. However, data on NK cells underlying the influence of stress, as published by various groups, are still contradictory; most results were acquired by flow cytometry using peripheral blood lymphocytes. Decidual NK cells have an unusual phenotype, $\mathrm{CD} 3^{-} \mathrm{CD} 16^{-} \mathrm{CD} 56^{+++}$, distinguishing them from peripheral blood NK cells, which might explain the different observations on stress and NK cells in different experimental settings.

Despite several studies relating stress with reproductive failure, the question still remains as to whether psychological stress is a possible cause or it only represents a consequence of the reproductive failure. Nonetheless the response to stress is variable in different types of people. Interestingly, in murine models there is a genetic determinant in response to stress that causes infertility in $\mathrm{A} / \mathrm{J}$ strain mice, and abortions in $\mathrm{C} 3 \mathrm{H}$ strain mice. ${ }^{17}$ These findings suggest that women with reproductive failure might have some specific characteristics that have escaped evaluation to date. Future studies should assess whether women with reproductive

\section{REFERENCES}

1. Dubey AK, Plant TM. A suppression of gonadotropin secretion by cortisol in castrated male rhesus monkeys (Macaca mulatta) mediated by the interruption of hypothalamic gonadotropin-releasing hormone release. Biol Reprod. 1985;33:423-31. Crossref

2. Schedlowski M, Jacobs R, Stratmann G, Richter S, Hädicke A, Tewes U, et al. Changes of natural killer cells during acute psychological stress. J Clin Immunol. 1993;13:119-26. Crossref

3. Dhabhar FS, Miller AH, McEwen BS, Spencer RL. Effects of stress on immune cell distribution. Dynamics and hormonal mechanisms. J Immunol. 1995 May 15;154:551127. Crossref

4. Benschop RJ, Geenen R, Mills PJ, Naliboff BD, KiecoltGlaser JK, Herbert TB, et al. Cardiovascular and immune responses to acute psychological stress in young and old women: a meta-analysis. Psychosom Med. 1998;60:290-6. Crossref

5. Shakhar K, Rosenne E, Loewenthal R, Shakhar G, Carp $\mathrm{H}$, Ben-Eliyahu S. High NK cell activity in recurrent miscarriage: what are we really measuring? Hum Reprod. 2006;21:2421-5. Crossref

6. Hosaka T, Matsubayashi H, Sugiyama Y, Izumi S, Makino T. Effect of psychiatric group intervention on natural-killer cell activity and pregnancy rate. Gen Hosp Psychiatry. 2002;24:353-6. Crossref

7. Landmann R. Beta-adrenergic receptors in human leukocyte subpopulations. Eur J Clin Invest. 1992;22 Suppl 1:30-6. Crossref

8. Benschop R, Rodriguez-Feuerhahn M, Schedlowski M. Catecholamine induced leukocytosis: early observations, current research, and future directions. Brain Behav Immun. 1996;10:77-91. Crossref

9. Friedman EH. Neurobiology of prenatal maternal blood pressure response to stress. Am J Obstet Gynecol. 1997:176,733. Crossref failure are more responsive to stressful stimuli, and whether these responses predict pregnancy outcome.

Considering the fact that women with reproductive failure are vulnerable to acute stress, they may be more likely to benefit from psychological intervention to improve the reproductive outcome. Despite these implications, the results of this study should be considered in light of small sample size.

\section{CONCLUSIONS}

Stress response is variable in different types of people. Women with reproductive failure have exaggerated acute stress response. Greater sympathetic response to stressor may increase the risk of miscarriage and Infertility.

\section{ACKNOWLEDGMENT}

I would like to thank my supervisor Professor Wang Qiong, all the nursing staff of Reproductive Medicine Centre, Gynaecology and Obstetrics Department, The First Affiliated Hospital, Sun Yat-sen University and to all the women who participated in this research.

10. Miller GE, Dopp JM, Myers HF, Stevens SY, Fahey JL. Psychosocial predictors of natural killer cell mobilization during marital conflict. Health Psychol. 1999;18:262-71. Crossref

11. Facchinetti F, Matteo M, Artini G, Volpe A, Genazzani A. An increased vulnerability to stress is associated with a poor outcome of in vitro fertilization-embryo transfer treatment. Fertil Steril. 1997;67:309-14. Crossref

12. C.B. Coulam, C. Goodman, R.G. Roussev, E.J. Thomason, K.D. Beaman. Systemic CD56+ cells can predict pregnancy outcome. Am. J. Reprod. Immunol. 1995;33: 40-6. Crossref

13. Kwak JY, Beaman KD, Gilman-Sachs A, Ruiz JE, Schewitz D, Beer AE. Up-regulated expression of CD56+, CD56+/ CD16+ and CD19+ cells in peripheral blood lymphocytes in pregnant women with recurrent pregnancy losses. Am J Reprod Immunol. 1995;34:93-9. Crossref

14. Yamada H, Kato EH, Kobashi G, Ebina Y, Shimada S, Morikawa $\mathrm{M}$, et al. NK cell activity in early pregnancy correlated with subsequent abortion with normal chromosomes in women with recurrent abortion. Am J Reprod Immunol. 2001;46:132-6. Crossref

15. Beer AE, Kwak JY, Ruiz JE. Immunophenotypic profiles of peripheral blood lymphocytes in women with recurrent pregnancy losses and in infertile women with multiple failed in vitro fertilization cycles. Am J Reprod Immunol. 1996;35:376-82. Crossref

16. Fukui A, Fujii S, Yamaguchi E, Kimura H, Sato S, Saito Y. Natural killer cell subpopulations and cytotoxicity for infertile patients undergoing in vitro fertilization. Am J Reprod Immunol. 1999;41:413-22. Crossref

17. Clark DA, Banwatt D, Chaouat G. Stress-triggered abortion in mice prevented by alloimmunization. Am J Reprod Immunol 1993;29:141-7. Crossref 